\title{
SURVIVAL OF ESCHERICHIA COLI O157:H7 CO-CULTURED WITH DIFFERENT LEVELS OF PSEUDOMONAS FLUORESCENS AND LACTOBACILLUS PLANTARUM ON FRESH BEEF
}

\author{
P. A. Tshabalala, H. L. de Kock, E. M. Buys*
}

University of Pretoria, Department of Food Science, Private Bag x20, Hatfield, South Africa.

Submitted: June 19, 2010; Returned to authors for corrections: November 15, 2010; Approved: June 07, 2012.

\begin{abstract}
The purpose of this study was to investigate the effect of different levels of Pseudomonas fluorescens $\left(10^{2}\right.$ and $\left.10^{6} \log _{10} \mathrm{cfu} / \mathrm{ml}\right)$ and Lactobacillus plantarum $\left(10^{2}\right.$ and $\left.10^{4} \log _{10} \mathrm{cfu} / \mathrm{ml}\right)$ on the growth of Escherichia coli O157:H7 on beef loins. Beef loins inoculated with E. coli O157:H7 and P. fluorescens were aerobically stored for 7 days at $4{ }^{\circ} \mathrm{C}$, while those inoculated with E. coli O157:H7 and L. plantarum were vacuum packaged and stored for 8 weeks at $4{ }^{\circ} \mathrm{C}$. Aerobic Plate Counts (APC), E. coli O157:H7 and either P. fluorescens or L. plantarum counts were determined at different storage intervals. For the aerobically packaged beef loins, E. coli O157:H7 was detected throughout the 7 day storage period regardless of the $P$. fluorescens level in the inoculum. For the vacuum packaged beef loins, similar inoculum levels of $E$. coli O157:H7 and L. plantarum allowed E. coli O157:H7 to survive until week 5 of storage, while a higher inoculum level of L. plantarum inhibited E. coli O157:H7 from week 3. Once fresh beef has been contaminated with E. coli O157:H7, the level of $P$. fluorescens in the background flora does not inhibit its survival and growth. However, under vacuum storage, the application of L. plantarum as a biopreservative inhibits the survival of E. coli O157:H7 on beef. The higher the level of L. plantarum in the system, the earlier the onset of the inhibition. Farmers and abattoirs have to strengthen preventive strategies to eliminate contamination of beef carcasses with E. coli O157:H7.
\end{abstract}

Key words: aerobic storage, vacuum package, E. coli O157:H7, P. fluorescens, L. plantarum

\section{INTRODUCTION}

There is evidence that some slaughter animals in South Africa shed E. coli O157:H7 at the time of slaughter, which creates an opportunity for this pathogen to be present on meat and meat products. The organism has been found in $19 \%$ and $7 \%$ of slaughter cattle feces and carcasses, respectively. Similarly, it was found in $8 \%$ and $1 \%$ of sheep feces and carcasses, and in $31 \%$ and $1 \%$ of horse feces and carcasses (Veterinary Services, Gauteng Provincial Department of Agriculture, unpublished). Spoilage and pathogenic bacteria compete for available substrates in food to survive. Psychrotrophic bacteria especially of the genus Pseudomonas are common on meat. These organisms have been identified in numerous studies as the major spoilage organisms in refrigerated fresh meats $(2,12)$ partly due to their ability to

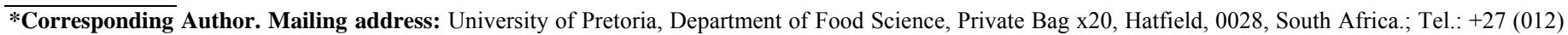
420-3209 Fax: +27 (012) 420-2839.; E-mail: elna.buys@up.ac.za 
form quorum sensing facilitated biofilms (14).

In South Africa, the meat industry utilizes vacuum packing to extend the shelf life of beef products for transportation, which is at times over considerable distances, since the final destination of these products often includes neighboring countries (24). Lactic acid bacteria (LAB) are facultative anaerobes which are antagonistic against many microorganisms including spoilage and pathogenic bacteria (1). Previously, research focused on the inhibitory effect of $L$. plantarum on E. coli $\mathrm{O} 157: \mathrm{H} 7$ in a range of food products including acidic fruit juices (29), processed meat products (22), and ground beef $(19,25)$, but there is no evidence of work conducted on whole beef loins. Since Pseudomonads and LAB are natural contaminants of foods of animal origin, which can also be contaminated by E. coli $\mathrm{O} 157: \mathrm{H} 7$, it is important to understand how these will affect the survival and growth of $E$ coli.O157:H7 on aerobically and vacuum stored beef. Furthermore, it was suggested that decontamination techniques used in developed countries led to very low numbers of background microorganisms on fresh meat, resulting in reduced competition between such microorganisms and food pathogens. Fresh food products that contain $10^{5}$ cells/g of harmless microbiota are less likely to allow low numbers of pathogens to proliferate than ones that contain $10^{3}$ cells/g (13). The aim of this study was to investigate the effect of different levels of competitive, spoilage bacteria, P. fluorescens and $L$. plantarum on the survival and growth of E. coli $\mathrm{O} 157: \mathrm{H7}$ on aerobically and vacuum packaged stored $\left(4{ }^{\circ} \mathrm{C}\right)$ beef, respectively.

\section{MATERIALS AND METHODS}

\section{Bacterial strains}

E. coli O157:H7 strain UT 10, isolated from meat, was obtained from the Agricultural Research Council, Onderstepoort, South Africa. This strain was used for both experiments 1 and 2. For experiment $1 P$. fluorescens ATCC 13525 strain was used (Kiwk stik; MediMark, France). For experiment 2 L. plantarum ATCC 8014 (MediMark) strain was used.

\section{Preparation of beef loins}

Vacuum packaged deboned beef loin (M. longissimus dorsi) was purchased from a local butchery. Under aseptic conditions, the external layer (approximately $1 \mathrm{~cm}$ ) of the muscle was removed within a biological safety cabinet (Labaire, France). The internal portion was cut aseptically into $25 \mathrm{~g}$ blocks using a sterile metallic sampler. Two sterile pieces were subsequently analyzed to determine the total aerobic counts after sterilization, which were $<10 \log _{10} \mathrm{cfu} / \mathrm{cm}^{2}$.

\section{Preparation of working cultures}

E. coli O157:H7 strain was cultivated in Brain Heart Infusion Broth (BHIB) CM 225 (Oxoid, Hamisphre, England) and incubated at $37^{\circ} \mathrm{C}$ for $24 \mathrm{~h}$. The $P$. fluorescens strain was grown on Pseudomonas Agar CM 559 with selective SR 103 and incubated at $25^{\circ} \mathrm{C}$ for $72 \mathrm{hrs}$, while $\mathrm{LAB}$ for experiment 2 was cultivated on de Man, Rogosa and Sharpe, (MRS) agar CM 359, (Oxoid) and incubated at $30{ }^{\circ} \mathrm{C}$ for 48 hours. 0.5 McFarland standard (Andrew, 2005) was used to prepare cultures containing $10^{2} \log _{10} \mathrm{cfu} / \mathrm{ml}$ of $E$. coli $\mathrm{O} 157: \mathrm{H} 7$, as well as $10^{2}$ and $10^{6} \log _{10} \mathrm{cfu} / \mathrm{ml}$ of both $P$. fluorescens and $L$. plantarum. Serial dilutions of the bacterial cultures were made using Buffered Peptone Water (BPW) CM 509, (Oxoid) and plated onto Plate Count Agar (PCA) CM 463, (Oxoid) for the determination of the exact number of $\mathrm{cfu} / \mathrm{ml}$. A cocktail inoculum of $300 \mathrm{ml}$ was prepared by mixing $150 \mathrm{ml}$ of each bacterial inoculum at the concentration of $10^{2} \log _{10} \mathrm{cfu} / \mathrm{ml}$. Another cocktail inoculum was prepared by mixing $150 \mathrm{ml}$ volumes of $10^{2} \log _{10} \mathrm{cfu} / \mathrm{ml}$ E. coli O157:H7 inoculum with $10^{6} \log _{10} \mathrm{cfu} / \mathrm{ml}$ P. fluorescens and that of $10^{2} \log _{10} \mathrm{cfu} / \mathrm{ml} E$. coli O157:H7 and $10^{4} \log _{10} \mathrm{cfu} / \mathrm{ml}$ L. plantarum.

\section{Inoculation of beef loins}

For each treatment, sterile pieces of $25 \mathrm{~g}$ of beef were individually submerged into the inoculum for $10 \mathrm{~min}$ to allow 
for bacterial attachment. Inoculated beef pieces were air-dried for 5 minutes. In experiment 1 , the inoculated beef pieces were packaged individually in zip-lock plastic pouches $\left(\mathrm{PVC}, \mathrm{O}_{2}\right.$ transmission $>10000 \mathrm{~cm}^{3} / \mathrm{m}^{2}$ per $\left.24 \mathrm{~h} / \mathrm{atm}\right)(150 \mathrm{~mm} \times 180 \mathrm{~mm} \times$ $40 \mathrm{~mm}$ ) and stored aerobically at $4{ }^{\circ} \mathrm{C}$ for a total of 7 days. Duplicate samples were collected and analyzed after 0, 2, 3, 5 and 7 days to determine E. coli O157:H7and P. fluorescens counts, as well as the APC. The same procedure as in experiment 1 was used to inoculate sterile beef pieces, which were subsequently separately placed in vacuum bags $(150 \mathrm{~mm}$ x $200 \mathrm{~mm}$ ), vacuum sealed and stored at $4{ }^{\circ} \mathrm{C}$ for 2 months. Samples were analyzed after $0,1,2,3,4,5,6,7$ and 8 weeks of storage for E. coli O157:H7, L. plantarum and APC. All experiments were carried out in triplicate with duplicate samples analyzed at each storage interval in duplicate plates.

\section{Microbiological analysis of inoculated beef loins}

During each sampling period, duplicate subsamples of 25 $\mathrm{g}$ were homogenized with $225 \mathrm{ml}$ of $0.1 \% \mathrm{BPW}$ in a stomacher (Seward 400, Seward, London, United Kingdom) and subsequent decimal dilutions were prepared and plated. For the enumeration of E. coli O157:H7, sorbitol McConkey (SMAC) Agar CM 813, (Oxoid) with selective supplement SR 172, (Oxoid) was used. SMAC plates were incubated at $37^{\circ} \mathrm{C}$ for 24 hours.

\section{Statistical analysis}

Data were analyzed by two way Analysis of variance (ANOVA) including the interaction effect using Statistica 7 (Statsoft Inc., Tulsa, Oklahoma, USA, 2003) to determine if levels of E. coli O157:H7 $\left(10^{2} \log _{10} \mathrm{cfu} / \mathrm{ml}\right)$, P. fluorescens $\left(10^{2}\right.$ and $\left.10^{6} \log _{10} \mathrm{cfu} / \mathrm{ml}\right)$ and L. plantarum $\left(10^{2}\right.$ and $10^{4} \log _{10}$ $\mathrm{cfu} / \mathrm{ml}$ ) and storage time (Day 0, 2, 3, 5, 7) under aerobic storage and 8 weeks ( 1 week interval) under vacuum storage significantly (95\% confidence interval) affect survival and growth of E. coli O157:H7 on meat. All samples were analyzed in duplicate and each experiment was repeated three times. Means were separated by Fisher's Least Significant
Difference (LSD) analysis.

\section{RESULTS}

\section{Effect of different levels of $E$. coli $0157: H 7$ and $P$. fluorescens in the inoculum on the growth of $E$. coli 0157:H7 on beef loins}

The $P$. fluorescens inoculum level did not influence the survival and growth of $E$. coli $\mathrm{O} 157: \mathrm{H7}(\mathrm{p}=0.62)$, while growth of E. coli O157:H7 was affected by the storage time $(\mathrm{p}<0.05)$. There was a significant $(\mathrm{p}<0.05)$ interaction between the inoculation level and time (level $\mathrm{x}$ time) on the growth and survival of E. coli O157:H7. Inoculum level and storage time did not influence $P$. fluorescens count $(\mathrm{p}=0.20)$ and APC $(p=0.94)$.

When similar levels $\left(10^{2} \log _{10} \mathrm{cfu} / \mathrm{ml}\right)$ of E. coli O157:H7 and P. fluorescens were combined, E. coli O157:H7 was not recovered from beef (Fig 1a) on day 0. By day 2 of storage, the E. coli O157:H7 count reflected the level that was inoculated, $2.54 \log _{10} \mathrm{cfu} / \mathrm{cm}^{2}$. E. coli O157:H7 count significantly $(\mathrm{p}<0.05)$ increased until day 3 . From then on, no further growth occurred. By day 7, the E. coli O157:H7 population was recoverable at levels of $4.44 \log _{10} \mathrm{cfu} / \mathrm{cm}^{2}$. E. coli $\mathrm{O} 157: \mathrm{H} 7$ increased by 2 log when comparing levels at days 2 and 7.

Under the same experimental conditions, P. fluorescens showed a 2 day lag phase, as the counts enumerated during day 0 and day 2 remained at the same level (Figure 1a). There was a significant $(\mathrm{p}<0.05)$ increase in growth by day 3 of storage, which remained the same until day 5. The highest $P$. fluorescens growth population was recorded at day 7. Growth of $P$. fluorescens increased by $4 \log$ during the storage period of 7 days. APC remained relatively constant, with a significant increase $(p<0.05)$ between the counts enumerated at day 0 compared to day 5 and day 7. Similar levels of E. coli O157:H7 and $P$. fluorescens were recovered on day 3. $P$. fluorescens counts on days 5 and 6 were higher than E. coli O157:H7 counts during the same period. 
Growth of E. coli O157:H7 showed a 2 day lag phase when combined with $10^{6} \log _{10} \mathrm{cfu} / \mathrm{ml} P$. fluorescens inoculum (Fig. 1b). By day 3, growth increased significantly $(\mathrm{p}<0.05)$ compared to start of the storage period. The highest E. coli O157:H7 growth population was achieved from day 5 and maintained until the end of the experiment. The growth of $E$. coli O157:H7 under both experimental environments $(P$. fluorescens inoculation levels $10^{2}$ or $10^{6} \log _{10} \mathrm{cfu} / \mathrm{ml}$ ) was similar by day 7 indicating that the level of $P$. fluorescens did not affect the growth of $E$. coli O157:H7.

The growth of $P$. fluorescens (Fig 1b) showed a similar pattern as E. coli $\mathrm{O} 157: \mathrm{H} 7$ at the beginning of the storage period with a 2-day lag phase. By day 3, there was a significant $(p<0.05)$ increase in growth, which remained at the same level until day 5. A significant $(\mathrm{p}<0.05)$ increase in $P$. fluorescens growth was observed at day 7. P. fluorescens increased by $3 \log$ over the storage period. APC followed a similar trend to $P$. fluorescens (Fig 1b).

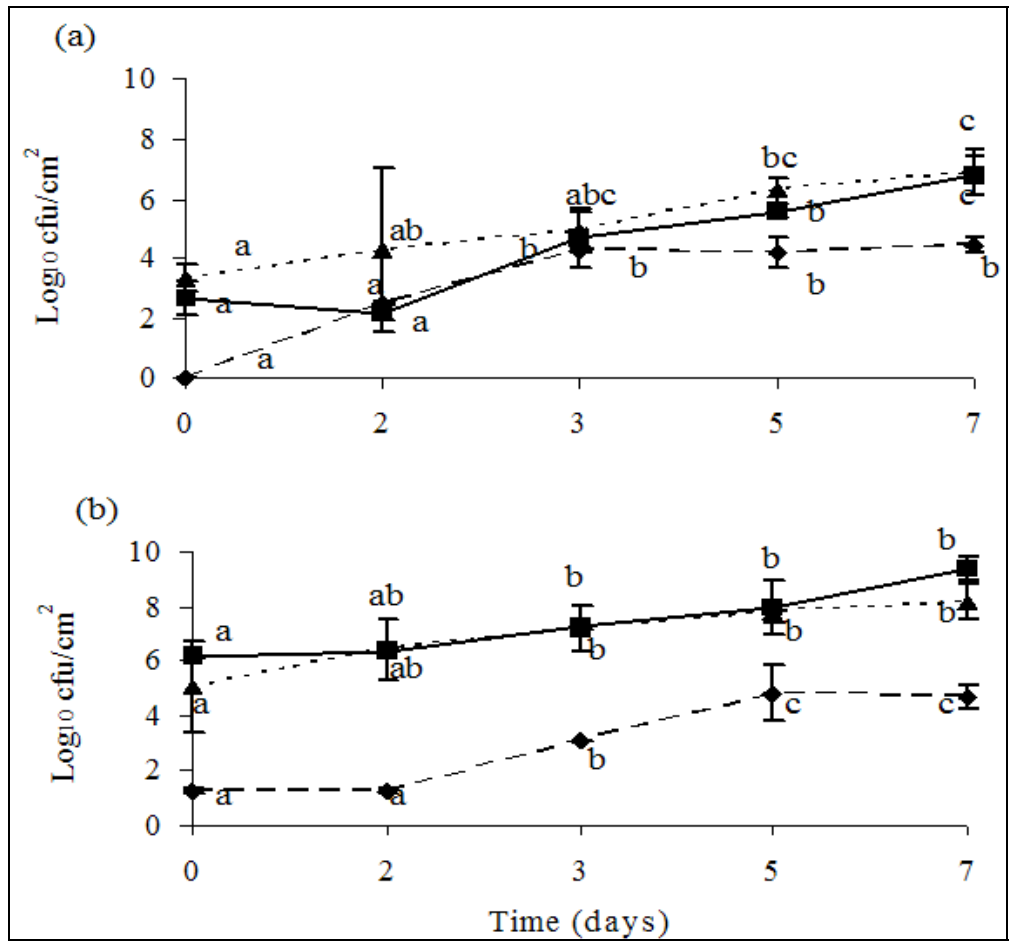

Figure 1. Effect of inoculation levels of $P$. fluorescens $\left(10^{2}\right.$ and $\left.10^{6}\right)$ on the growth of inoculated E. coli O157:H7 $\left(10^{2} \log _{10} \mathrm{cfu} / \mathrm{ml}\right)$ on sterile beef $(\mathrm{n}=60)$, aerobically packaged and stored for 7 days at $4{ }^{\circ} \mathrm{C}$. (a) Inoculum cocktail: $10^{2} \log _{10} \mathrm{cfu} / \mathrm{ml} \mathrm{E} \mathrm{coli} \mathrm{O} 157: \mathrm{H} 7$ and $10^{2}$ $\log _{10} \mathrm{cfu} / \mathrm{ml}$ P. fluorescens in the inoculum; (b) Inoculum cocktail: $10^{2} \log _{10} \mathrm{cfu} / \mathrm{ml}$ E. coli O157:H7 and $10^{6} \log _{10} \mathrm{cfu} / \mathrm{ml}$ P. fluorescens in the inoculum. Means for the same bacterium $\bullet$ E. coli O157:H7 - P. fluorescens $\boldsymbol{\Delta}$ APC with different letter notations are significantly different at $\mathrm{p}<0.05$.

Effect of different levels of $E$. coli $0157: H 7$ and $L$. plantarum in the inoculum on the growth of $E$. coli 0157:H7 on beef loins

The level of L. plantarum in the inoculum and the storage time significantly $(\mathrm{p}<0.05)$ affected the survival and growth of E. coli O157:H7 and L. plantarum on beef pieces, while both factors did not affect APC $(\mathrm{p}=0.37)$. The onset of $E$. coli O157:H7 inhibition was also affected by the level of $L$. plantarum in the inoculum.

When the levels of E. coli O157:H7 and L. plantarum were similar $\left(10^{2} \log _{10} \mathrm{cfu} / \mathrm{ml}\right)$ in the inoculum suspension (Figure 2a), L. plantarum did not show immediate inhibition of 
E. coli O157:H7. There was a similar numerical increase in the $E$. coli O157:H7 count recorded at week 1 and week 2. The highest growth population of $E$. coli $\mathrm{O} 157: \mathrm{H} 7$ was determined at week 3 after which no more growth occurred. Instead, the E. coli O157:H7 population declined, on average, by 2 log by week 4 to $2.03 \log _{10} \mathrm{cfu} / \mathrm{cm}^{2}$. The decline in the E. coli $\mathrm{O} 157: \mathrm{H} 7$ population continued up to week 5 and was too low to detect by week 6 .

Similar to E. coli O157:H7, L. plantarum counts remained stable from the beginning of storage to week 1 . There was a significant $(\mathrm{p}<0.05)$ increase recorded at week 2 . At week 3 , the L. plantarum growth curve showed $1.11 \mathrm{log}$ increase compared to week 2. From week 3, L. plantarum counts remained similar until week 7 , indicating a 5 week long stationary phase, which was followed by a $1.4 \log$ decline recorded at week 8 , indicating the beginning of the death phase of $L$. plantarum. APC showed an increase by week 1 that continued until week 3 . APC then remained constant for the remainder of the storage time.
When a lower level of E. coli O157:H7 $\left(10^{2} \log _{10} \mathrm{cfu} / \mathrm{ml}\right)$ was combined with a higher level of L. plantarum $\left(10^{4} \log _{10} \mathrm{cfu} / \mathrm{ml}\right)$ in the inoculum (Fig. 2b), the adverse effect of L. plantarum on the growth and survival of E. coli $\mathrm{O} 157: \mathrm{H} 7$ was recorded earlier compared to the onset of such an effect when the same levels of $E$. coli $\mathrm{O} 157: \mathrm{H} 7$ and L. plantarum in the inoculum suspension. Low levels of E. coli O157:H7 survivors were detected at week 1 and week 2. From week 3 onwards, E. coli O157:H7 was not recovered from beef loin pieces. The L. plantarum growth curve showed significant growth of the organism by week 2), which remained at the same level by the end of the experiment. However, the count of $L$. plantarum at week 4 was significantly higher $(\mathrm{p}<0.05)$ compared to that recorded at week 2. APC were relatively constant throughout the storage period. APC recorded during week 8 was significantly higher $(\mathrm{p}<0.05)$ compared to weeks 0 and 1 . L. plantarum count increased by $2 \log$ when comparing the starting count and the count at the end of storage.

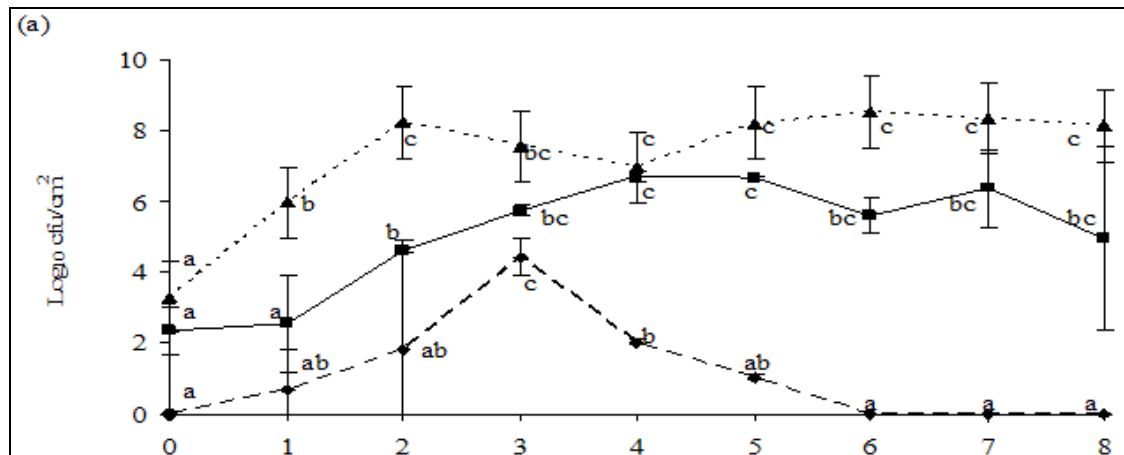

(b)

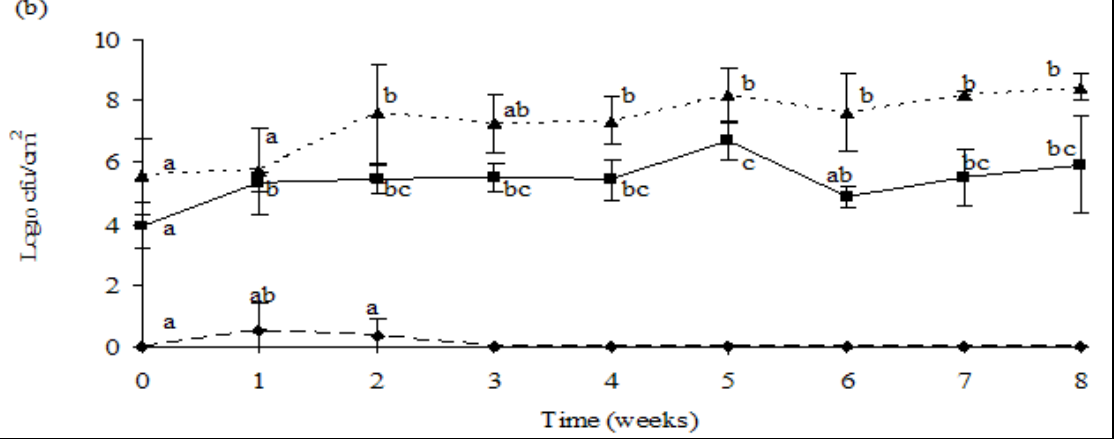

Figure 2. Effect of inoculation levels of L. plantarum $\left(10^{2}\right.$ and $\left.10^{4} \log _{10} \mathrm{cfu} / \mathrm{ml}\right)$ on the growth of inoculated E. coli O157:H7 (10 ${ }^{2} \log _{10}$ $\mathrm{cfu} / \mathrm{ml})$ on sterile beef $(\mathrm{n}=108)$, vacuum packaged and stored for 8 weeks at $4{ }^{\circ} \mathrm{C}$. (a) Inoculum cocktail: $10^{2} \log _{10} \mathrm{cfu} / \mathrm{ml}$. coli O157:H7 and $10^{2} \log _{10} \mathrm{cfu} / \mathrm{ml} \mathrm{L.} \mathrm{plantarum} \mathrm{in} \mathrm{the} \mathrm{inoculum;} \mathrm{(b)} \mathrm{Inoculum} \mathrm{cocktail:} 10^{2} \log _{10} \mathrm{cfu} / \mathrm{ml}$ E. coli $\mathrm{O} 157: \mathrm{H} 7$ and $10^{4} \log 10$ $\mathrm{cfu} / \mathrm{ml}$ L. plantarum in the inoculum. Means for the same bacterium, with different letter notations $\downarrow$ E. coli O157:H7 — L. plantarum $\Delta$ APC are significantly different at $\mathrm{p}<0.05$. 


\section{DISCUSSION}

Effect of different levels of $E$. coli $0157: H 7$ and $P$. fluorescens in the inoculum on the growth of $E$. coli 0157:H7 on beef loins

The application of a constant level of E. coli O157:H7 with either a similar or a higher level of $P$. fluorescens in the inoculum showed interesting growth patterns for both bacteria, as well as the APC. E. coli O157:H7 could not be quantified immediately after inoculation at day 0 , while $P$. fluorescens was detected. The inability to recover E. coli O157:H7 from inoculated samples is in agreement with Thran et al. (27) who did not detect E. coli O157:H7 in rumen contents when testing directly within $24 \mathrm{~h}$ of storage. Detection was only achieved after enrichment. The results of this study, showed that $18 \mathrm{~h}$ cultures of E. coli O157:H7 and P. fluorescens required 2 days to adapt and start growing on meat stored aerobically at $4{ }^{\circ} \mathrm{C}$.

By day 3, under similar inoculation levels, the growth populations of both organisms had increased significantly, implying that there was no antagonism between these organisms before day 3. An antagonistic interaction between E. coli O157:H7 and P. fluorescens was observed after day 3, wherein, E. coli O157:H7 stopped growing, while $P$. fluorescens continued to grow and reached its maximum growth density at day 7. The retardation of E. coli O157:H7 might be due to the effects of the available nutrients on meat, the suppression by background $P$. fluorescens or the combined effect from both nutrients and P. fluorescens. Tsigarida et al. (28) reported an accelerated consumption of glucose by pseudomonads when co-cultured with other bacteria. Free glucose is a minor component of meat, 0.1 to $0.5 \%(10,20)$. Therefore, Pseudomonas species have a competitive advantage over other organisms due to their ability to transform glucose rapidly to gluconate in chilled muscle foods stored aerobically (6). The presence of glucose enhances the inhibition of E. coli O157:H7 by Pseudomonas spp., particularly at low storage temperatures (23). In the absence of glucose, the inhibition of E. coli $\mathrm{O} 157: \mathrm{H} 7$ was weak at temperatures above $10{ }^{\circ} \mathrm{C}$, while at $25{ }^{\circ} \mathrm{C}$, there was minimal inhibition of the pathogen, irrespective of glucose (23).

Growth of bacteria on the surface of meat depends on the rate of diffusion of fermentable substrates from within the meat to the surface (10). When the rate of transfer of such substrates slows down the rate of growth declines to the point where the rate at which the substrates become available is only sufficient for cell maintenance and not growth. Therefore, the cessation in growth between days 3 and 5 could signify the period that $P$. fluorescens had to change their metabolism to utilize amino acids and lactic acid upon the depletion of glucose (10). Furthermore, Pseudomonads synthesize siderophores that function to sequester available iron (16). Therefore, $P$. fluorescens could also have exerted a siderophore inhibitory effect (5), on E. coli O157:H7, resulting in levels of the latter not increasing after 3 days of storage at $4{ }^{\circ} \mathrm{C}$. The APC curve showed a similar pattern to that of $P$. fluorescens, confirming that the $P$. fluorescens cells contributed mostly to the APC of the sterilized beef loin samples, as would have been expected.

When beef pieces were inoculated with a higher level $\left(10^{6}\right.$ $\left.\log _{10} \mathrm{cfu} / \mathrm{ml}\right)$ of $P$. fluorescens, $P$. fluorescens showed a slower growth rate, unlike when similar levels were used, which could probably be due to competition among $P$. fluorescens for growth space on the limited growth area. E. coli O157:H7 continued to grow in the presence of $P$. fluorescens, even when the levels of $P$. fluorescens had increased to $10^{7} \log _{10} \mathrm{cfu} / \mathrm{cm}^{2}$, a level attributed to slime and off-flavours formation (20). Therefore, although E. coli O157:H7 survived until the end of the experiment, beef loins would have been rejected based on appearance.

The continued increase in E. coli O157:H7 growth population between days 3 and 5 demonstrates that E. coli O157:H7 competes well with P. fluorescens on meat. APC growth curve was similar to that observed when the levels of $E$. coli $\mathrm{O} 157: \mathrm{H} 7$ and $P$. fluorescens were similar. In this study, both inocula levels of $P$. fluorescens did not inhibit the growth of E. coli O157:H7 on refrigerated beef loins. The level of $P$. fluorescens does not inhibit growth of E. coli $\mathrm{O} 157: \mathrm{H} 7$ on 
aerobically stored beef. E. coli O157:H7 survived at levels that can cause food-borne illness regardless of the level of $P$. fluorescens on meat. Comprehensive control strategies at primary production and slaughtering levels are required to eliminate the contamination of meat and meat products with $E$. coli O157:H7.

Effect different levels of $E$. coli $0157: H 7$ and L. plantarum in the inoculum on the growth of $E$. coli $0157: H 7$ on beef loins

When beef pieces were inoculated with similar levels of E. coli O157:H7 and L. plantarum, E. coli O157:H7 growth was only determined after 3 weeks of storage. The ability of $E$. coli $\mathrm{O} 157: \mathrm{H} 7$ to grow under acidic conditions could be as a result of acid tolerance. E. coli O157:H7 acquired increased acid tolerance after being incubated in acidic washings of sublethal $\mathrm{pH}$ at $4{ }^{\circ} \mathrm{C}(26)$. Likewise, in this study during the lag phase, the $\mathrm{pH}$ of beef could have decreased due to $L$. plantarum activities, exposing E. coli $\mathrm{O} 157: \mathrm{H} 7$ cells to acidic conditions. The cells then become adapted to acidic conditions and continued to grow, hence the exponential cell growth by week 3. In support of the findings of this study, Dykes et al. (7) concluded that E. coli O157:H7, unlike generic E. coli was less inhibited by the drop in $\mathrm{pH}$. Low temperature and acidification enhanced the acid tolerance of E. coli O157:H7 on vacuum packaged beef (7).

L. plantarum produces plantaricin, a bacteriocin with inhibitory activity towards both Gram positive and Gram negative bacteria, including food pathogens (Listeria, Staphylococcus and Salmonella) $(15,8,9,17,18)$. In this study, as soon as L. plantarum cells entered the stationary growth phase, E. coli O157:H7 counts showed a steady decline in growth. After week 6, E. coli O157:H7 was not recovered from beef samples. The inhibition of E. coli O157:H7 growth could be attributed to the effect of plantaricins produced by $L$. plantarum after week 3 . This observation corresponds to the reported production of bacteriocins by $L$. plantarum when its growth transcends from exponential to stationary phase $(4,11)$.
The growth curve of $L$. plantarum showed that $L$. plantarum cells required 1 week before growth could be detected. Similarly, in another study, LAB cells were only detected from vacuum packaged goat minced meat after a 9 day storage period at $4{ }^{\circ} \mathrm{C}(3)$. The inability of $L$. plantarum to grow exponentially could be due to the storage temperature of $4{ }^{\circ} \mathrm{C}$. This is in keeping with the findings of Paynter et al. (21) who found that L. plantarum did not grow at $4{ }^{\circ} \mathrm{C}$ for 56 days, while growth occurred at higher incubation temperatures from 20 to $37{ }^{\circ} \mathrm{C}$. As expected, the APC growth curve showed cells entering the stationary growth phase from week 2 onwards until the end of the experiment, a similar trend to L. plantarum.

Unlike with similar levels of E. coli O157:H7 and $L$. plantarum, the inhibition of E. coli O157:H7 at the higher inoculation level $\left(10^{4} \log _{10} \mathrm{cfu} / \mathrm{ml}\right)$ occurred earlier. There was insignificant $E$. coli O157:H7 growth initially and the organism was not recovered at all from meat samples from week 2 onwards. The earlier inhibition of E. coli O157:H7 corresponded to the earlier entry of L. plantarum cells into the stationary phase, signifying a possible earlier onset of the production of plantaricins. This result shows that plantaricins, lower storage temperature $\left(4^{\circ} \mathrm{C}\right)$, higher level of L. plantarum in the inoculum and vacuum packaging had a combined inhibitory effect on the growth of $E$. coli O157:H7 on beef.

On vacuum packaged beef, L. plantarum culture treatment is beneficial in inhibiting the survival and growth of E. coli O157:H7. The higher the cell suspension of L. plantarum, the earlier the onset of the inhibition of E. coli O157:H7. Further studies to test the application of $L$. plantarum as a bio preservation technology are needed.

\section{REFERENCES}

1. Ammor, S.; Tauveron, G.; Dufour, E.; Chevallier, I. (2006). Antibacterial activity of lactic acid bacteria against spoilage and pathogenic bacteria isolated from the same meat small-scale facility: Behavior of pathogenic and spoilage bacteria in dual species biofilms including a bacteriocin-like-producing lactic acid bacteria. Food Control $17,454-461$. 
2. Ayres, J.C. (1960). The relationship of organisms of genus Pseudomonas to the spoilage of meat, poultry and eggs. J. Appl. Bacteriol. 23, 471-486.

3. Babji, Y.; Murthy, T.R.K. (2000). Effect of inoculation of mesophilic lactic acid bacteria on microbial and sensory changes of minced goat meat during storage under vacuum and subsequent aerobic storage. Meat Sci. 54 (2), 197-202.

4. Bárcena, J.M.B.; Sińriz, F.; de Llano, D.G.; Rodrĩguez, A.; Suárez, J.E. (1998). Chemostat production of plantaricin by Lactobacillus plantarum LL441. Appl. Environ. Microbiol. 64 (9), 3512-3514.

5. Cheng, C.M.; Doyle, M.P.; Luchansky, J.B. (1995). Identification of Pseudomonas fluorescens strains isolated from raw pork and chicken hat produce siderophores antagonistic towards food-borne pathogens. $J$. Food Prot. 58, 1340-1344.

6. Drosinos, E.H.; Board, R.G. (1994). Metabolic activities of pseudomonads in batch cultures in extract of mince lamb. J. Appl. Bacteriol. 77, 613-620.

7. Dykes, G.A.; Moorhead, S.M.; Roberts, S.L. (2001). Survival of Escherichia coli O157:H7 and Salmonella on chill-stored vacuum or carbon dioxide packaged primal beef cuts. Int. J. Food Microbiol. 64 (3), 401-405.

8. Enan, G.; Alalyan, S.; Abdel-Salam, H.A.; Debevere, J. (2002). Inhibition of Listeria monocytogenes LMG10470 by plantaricin UG1 in vitro and in beef meat. Hahrung 46 (6), 411-414.

9. Fricourt, B.V.; Barefoot, S.F.; Testin, R.F.; Hayasaka, S.S. (1994). Detection and activity of plantaricin $\mathrm{F}$ an antibacterial substance from Lactobacillus plantarum BF001 isolated from processed channel catfish. J. Food Prot. 57 (8), 698-702.

10. Gill, C.O. (1976). Substrate limitation of bacterial growth at meat surfaces J. Appl. Bacteriol. 41, 401-410

11. González, B.; Arca, P.; Mayo, B.; Suárez, J.E. (1994). Detection, purification and partial characterization of plantaricin $\mathrm{C}$, a bacteriocin produced by a Lactobacillus plantar strain of dairy origin. Appl. Environ. Microbiol. 60, 2158-2163.

12. Greer, G.G.; Jeremiah, L.E. (1980). Effect of retail sanitation o the bacterial load and shelf-life of beef. J. Food Prot. 43, 277-287.

13. Jay, J.M. (1997). Do background microorganisms play a role in the safety of fresh foods? Trends Food Sci. Tech. 8, 421-424.

14. Jay, J.M.; Vilai, J.P.; Hughes, M.E. (2003). Profile and activity of the bacterial biota of ground beef held from freshness to spoilage at $5-7^{\circ} \mathrm{C}$. Int. J. Food Microbiol. 81, 105-111.

15. Kodama, R. (1952). Studies on lactic acid bacteria. Part 11. Lactolin, a new antibiotic substance produced by lactic acid bacteria. J. Antibiot. 5, $72-74$.

16. Laine, M.H.; Karwoski, M.T.; Raaska, L.B.; Sandholm, T.M.M. (1996). Antimicrobial activity of Pseudomonas spp. against food poisoning bacteria and moulds. Lett. Appl. Microbiol. 22, 214-218.

17. Lash, B.W.; Mysliwiec, T.H.; Gourama, H. (2005). Detection and partial characterization of a broad-range bacteriocin produced by Lactobacillus plantarum (ATCC 8014). Food Microbiol. 22, 199-204.

18. Miñambres, R.; Rodrigo, A.; Carvajal, M.V.; Reverter, J.G.; Tomás, D. (2007). Molecular characterization and recuperation of bacteriocins produced by lactic acid isolated from dry cured-meat products. $J$. Biotechnol. 131 S235.

19. Nychas, G.J.; Dillon, V.M.; Board, R.G. (1988). Glucose the key substrate in the microbiological changes occurring in meat and certain products. Biotechnol. Appl. Biochem. 10, 203-231.

20. Nychas, G.J.E.; Skandamis, P.N.; Tassou, C.C.; Koutsoumanis, K.P. (2008). Meat spoilage during distribution. Meat Sci. 78 (1-2), 77-78.

21. Paynter, M.J.B.; Brown, K.A.; Hayasaka, S.S. (1997). Factors affecting the production of an antimicrobial agent, plantaricin F, by Lactobacillus plantarum BF001. Lett. Appl. Microbiol. 24, 159-165.

22. Riley, L.W.; Remis, R.S.; Helgerson, S.D.; McGee, H.B.; Wells, J.G.; Davis, B.R.; Hebert, R.J.; Olcott, H.M.; Johnson, L.M.; Hargrett, N.T.; Blake, P.A.; Cohen, M.L. (1983). Hemorrhagic colitis associated with a rare Escherichia coli serotype. New Engl. J. Med. 308, 681-685.

23. Samelis, J.; Sofos, J.N. (2002). Role of glucose in enhancing the temperature-dependent growth inhibition of Escherichia coli O157:H7 ATCC 43895 by a Pseudomonas sp. Appl. Environ. Microbiol. 68 (5), 2600-2604.

24. Shale, K. (2004). The prevalence of meat-borne and airborne Staphylococci in deboning areas of low - and high-throughput red meat abattoirs. P27. (Ph.D. Thesis. Central University of Technology, Free State. South Africa).

25. Smith, L.; Mann, J.E.; Harris, K.; Miller, M.F.; Brashears, M.M. (2005). Reduction of Escherichia coli O157:H7 and Salmonella in ground beef using lactic acid bacteria and the impact on sensory properties. J. Food Prot. 68 (8), 1587-1592.

26. Stopforth, J.D.; Skandamis, P.N.; Geornaras, I.; Sofos, J.N. (2006). Acid tolerance of acid-adapted and non acid-adapted Escherichia coli O157:H7 strains in beef decontamination runoff fluids or on beef tissue. Food Microbiol. 24 (5), 530-538.

27. Thran, B.H.; Hussein, H.S.; Redelman, D.; Fernandez, C.J. (2003). Influence of $\mathrm{pH}$ treatments on survival of Escherichia coli O157:H7 in continuous cultures of rumen contents. Exp. Biol. Med. 22, 365-369.

28. Tsigarida, E.; Boziaris, I.S.; Nychas, G-J.E. (2003). Bacterial synergism or antagonism in gel cassette system. Appl. Environ. Microbiol. 69 (12), 7204-7209.

29. Uljas, H.; Ingham, S.C. (1998). Survival of Escherichia coli O157:H7 in synthetic gastric fluid after cold and acid habituation in apple juice or trypticase soy broth acidified with hydrochloric acid or organic acids. $J$. Food Prot. 61 (8), 939-947. 